\title{
Research on the Competitive Advantage of the Firm
}

\subsection{Dominating Schools of Strategic Management}

The shortest definition of a good strategy can be boiled down to 'passion and discipline' (Obłój 2013). Passion means to retain an entrepreneurial spirit (eagerness for progress, flexibility, courage and optimism) - however old and extensive an organization may be. Discipline means to build a professional method for interpretation of the signals from the inside and outside of an organization and to retain a coherent logic of decision making. No less passionate and disciplined should be the work of researchers on strategic management, who-just like the business practitioners-try to find out how to create and run a perfect company. The answers they propose add to a highly diversified body of knowledge, which is often criticized for being too broad, unstructured and lacking identity (Lichtarski 2015; Sobczyk 2010; Trocki 2005). Still, given the applicable character of strategic management and management science in general, a wide range of proposals makes it more likely for business practitioners to find inspiration in a theory relating to a particular situation of a given company and its market environment (Krupski 2009a; Romanowska 2018).

The richness of ideas and concepts in strategic management does not mean they are all totally random. On the contrary, there are several streams of research (often called schools), which each integrate a distinctive way of thinking about the firm in the context of its strategy (Czakon 2014). This

(C) The Author(s) 2021

B. Deszczyński, Firm Competitive Advantage Through Relationship

Management, https://doi.org/10.1007/978-3-030-67338-3_1 
means that they try to provide a synoptic picture of the following areas of corporate activities (Obłój 1998, pp. 34-35):

- mission;

- business domain;

- competitive advantage;

- strategic goals;

- functional programmes.

Although these five build a consistent system of interdependencies, in this book the focus is on the origins of competitive advantage understood as the (relatively) stable generation of economic rents by the company (Czakon 2005). Strategic management is in essence the theory of corporate effectiveness (Obłój 2019), and the question of how firms achieve and sustain competitive advantage lies at the heart of its research agenda (Rumelt et al. 1995). Moreover, it seems the problem of competitive advantage is the only field that offers a chance to formulate possibly universal directives at the intersection of business practice and theory building. It is also the analysis of competitive advantage that initiates the creation of a business model, which transforms an abstract image of a company into its real operations (Banaszyk 2014; Obłój 2002). Hence, at least in terms of management science, the theory of competitive advantage has the potential to remain simultaneously actionable and generalizable.

The other four elements of strategy formulation described by Obłój (1998) need more specific studies in the context of a particular company or a group of companies, taking into account their size, structures, network embeddedness, industries or technologies. And thus, corporate mission describes the identity of an organization. Business domain answers the questions 'how', 'where' and 'when' a company should enter or leave a particular market. Strategic goals roughly reflect a company's response to a SWOT analysis. Functional programmes operationalize particular business activities (Krupski 2009b). Although useful, such studies largely deal with positivist or phenomenological descriptions, which are usually too idiosyncratic in nature to enable inductive enumeration and normative inference. As the normative significance of a theory depends on the fit between its assumptions and reality, the applicability of such models is most likely restricted to a small subgroup of firms whose characteristics fit the model's assumptions (Porter 1991). 
There have been numerous attempts to organize the body of knowledge on the theory of the firm, including strategic management as an associated theory. They are only partly compatible, because of their background, analytical cross-section, attention to detail and the passage of time (Zimniewicz 2014). As this book concerns relationship management underpinned by resource-based and dynamic capabilities theories, a comprehensive review of all possible classifications is not intended. However, some examples are chosen to gradually build a theoretical context of the envisioned relationship management (RM) mid-range theory in the context of sustainable competitive advantage creation.

$\mathrm{K}$. Conner distinguishes six research streams in the theory of the firm: five of these take the whole industry as the unit of analysis and are embedded in economic science (Industrial Organization EconomicsIOE); the sixth concentrates on the firm level (Resource Based View$\mathrm{RBV}$ ) and is explicitly embedded in management science. She briefly characterizes these schools as followings (1991, pp. 121-132):

- neoclassical perfect competition theory: firms as combiners of inputs;

- E. Mason and J. Bain's structure-conduct-performance (SCP) school: firms as output restrainers;

- J. Schumpeter's entrepreneurial school: firms as seekers of new ways of competing;

- Chicago school: firms as seekers of production and distribution efficiencies;

- R. Coase and O. Williamson's transaction cost economics: firms as avoiders of the cost of market exchange;

- RBV: firms as seekers of costly-to-copy inputs for production and distribution.

Conner's analysis illustrates, inter alia, how subsequent theories were dealing with gradual restructuring and concentration in many American industries, linking the mechanism of company growth with an attempt to achieve abnormal profits thanks to monopolistic rents. What is important in the context of this book is that her classification illuminates the similarities (apart from key distinctive features) between all IOE schools and the RBV. For example, the RBV sees a company as an input combiner (neoclassical view), which can achieve abnormal profits (J. Bain's view) thanks to new ways of competing based on innovations (J. Schumpeter's view) and efficiencies in acquiring, combining and deploying resources 
(Chicago school view). In turn, the specificity of resources constrains a company's strategic options ( $\mathrm{R}$. Coase and O. Williamson's view; Conner 1991, pp. 132-133). Thus, although intra-organizational analysis is central to the RBV, its proponents do not place the company in a total vacuum. The bridges between the RBV and some of the IOE theories have become even more evident since the notion of dynamic capabilities has enriched the original concept (Teece et al. 1997). A Schumpeterian style of evolutionary competition by adopting and creating innovations instead of price competition over existing products, or structuring relationships and posting 'performance bonds' as a mechanism for safeguarding business agreements in transaction cost economics, serves as a good example (Klein and Leffler 1981; Schumpeter 2010 (1950); Williamson 1983).

Reflecting on the strategy process formation, H. Mintzberg and J. Lampel initially proposed ten research streams in strategic management, which are given below with a brief description (Niemczyk 2009, pp. 13-14; Mintzberg and Lampel 1999, pp. 23-24):

- Design School: strategy as a project;

- Planning School: strategy as a long-term plan;

- Positioning School: strategy as taking positions towards competitors;

- Entrepreneurial School: strategy as a vision;

- Cognitive School: strategy making as a mental process;

- Learning School: strategy as an emergent incremental process;

- Power School: strategy making as a process of negotiations;

- Cultural School: strategy as a team process;

- Environmental School: strategy as a reaction to external situation;

- Configuration School: strategy as a transformation process.

What these authors highlight are different base disciplines, which build the original perspectives and the inspiration for strategy making: inter alia, anthropology, biology, economics, military science, politic science and psychology. They also indicate that blending different theories is a more fruitful process than erecting borders between them. And therefore H. Mintzberg and J. Lampel, for example, see the resource- and dynamic capabilities-based approach as a blend of the Design, Learning and Culture schools, whereas the work of M. Porter and his followers connects the Positioning and Power schools (1999, p. 26).

The highlighted theoretical intersections show that none of the theories are entirely outdated or can prove their superiority in every market/ 
industry/company situation. In fact, a comprehensive grand theory of the firm or a grand theory of competitive advantage cannot be based on one single school of strategic management. In order to better illustrate how competitive advantage is created in a given market context (e.g. B2B versus B2C, contractual versus non-contractual, quality-oriented market segments versus price-oriented market segments), more specialized mid-range theories are needed. These mid-range theories will inherit some general assumptions from their parenting grand theory. There are three such underlying options, which deal with the locus of competitive advantage:

- the locus of competitive advantage is external to the firm;

- the locus of competitive advantage lies inside of the firm;

- a hybrid approach.

The following section explains the essence of the dispute between the two principal external/internal approaches.

\subsection{The Discourse on the Locus of Competitive Advantage}

The notion of competitive advantage reveals a wide variety of approaches in measurement and application (Buckley et al. 1988). A general definition of competitiveness, "the above industry average manifested exploitation of market opportunities and neutralization of competitive threats" (Sigalas 2013 , p. 324), indicates that it is a relative phenomenon. In order to fully assess whether a company possesses a competitive advantage, it has to be compared to its rivals (Peteraf and Barney 2003). As, because of practical reasons, the verification of competitive advantage takes place predominately in the market, the notion of business performance and its (usually) financial measures arises. However, the potential to generate positive business results cannot, in the longer run, be detached from the individual situation of the firm. The resounding examples of Enron and more recently Lehman Brothers, who suddenly went bankrupt amid public scandal, remind us that competitive advantage is not only about today's results, but also about their sustainability.

Obviously, the sustainability of competitive advantage is not only endangered by speculative actions. For example, a company can successfully operate by applying functionally based marketing and by concentrating on 
the acquisition of random customers. If the number of floating customers who are not emotionally bound to any brand, company or individual employee is high enough, this strategy will temporarily pay off. Simultaneously, the results of such firms are a function of generic tactical activities, which do not build any insurmountable gap for competitors who have financial capacities to launch an extensive market expansion strategy (Bass et al. 2004; Coyne 1986). In this respect, their competence in making a profit through servicing the market is not comparable in terms of sustainability to those companies who have built their advantage on more idiosyncratic hard-to-imitate factors (Bharadwaj et al. 1993; Mawdsley and Somaya 2018). In other words, sustainable competitive advantage is achieved when it rests upon factors that resist erosion by simple duplication or replacement and that are updated in a timely manner to reflect the pace of technological change, natural business cycles, environmental constraints and emerging business opportunities (Barney 1986b; Bingham and Eisenhardt 2008).

The issue of time is reflected in the differences between the IOE and the RBV, which can be synthetized as a pair of contradictory approaches: short-term strategizing (IOE) versus long-term economizing (RBV). Strategizing means that the company particularly deeply analyses the behaviour and relative positions of its rivals (Williamson 1991). Moreover, it involves deliberate actions to influence the industry structure, for example by acquiring its competitors and enhancing the economies of scale cost reduction effect, or by creating entry barriers like industry standards and irreversible commitments (Porter 1980; Shapiro 1989). The more favourable its position, the more likely it is that a company will try to maximize profits by consciously restricting its output and setting prices far above the marginal cost and thereby securing a monopolistic rent (Teece 1984).

Economizing in the resource-based sense reflects the superiority of resources that the company possess. A familiar interpretation of D. Ricardo's concept of rent indicates that some production factors (resources) are more effective than the rest, and their owners can generate rents either through lower costs or by catering to customers' needs in a distinctively better way, or both (Montgomery and Wernerfelt 1988). The difference between monopolistic and Ricardian rents lies in the nature of limited supply. In a monopoly, supply is intentionally kept low to curb the price above equilibrium. The Ricardian rent is generated at maximum output because the uniqueness of the resources implies their limited 
character. The elastic expansion of supply is almost impossible, however high the price would be (Peteraf 1993).

A classic synthesis of the strategizing approach is represented in Porter's first article published in Harvard Business Review (1979; repeatedly cited elsewhere). It asserts the following assumptions:

- the environment determines the behaviour of a company;

- a strategy is the act of aligning a company and its environment;

- the success of a company (business unit) results from the rivalry in a particular industry;

- there are three generic ways of achieving competitive advantage: cost leadership, differentiation and focus (a combination of one of these two with a narrow specialization within an industry or an isolated niche).

In addition, Porter's familiar five forces model and diamond model of international competitiveness, as well as dozens of other concepts (e.g. decision-making matrixes and methods of strategic analysis), have delivered an effective managerial toolbox that is useful in strategizing to achieve an above-average performance (compared to an industry level). This feature is clearly distinctive and explains why the Positioning School has enjoyed, and still does, so much resonance with researchers, business consultants and managers (Obłój 2007).

However, there is another side to the coin. In his early work, Porter builds up his concepts on the SCP paradigm (Bain 1968). A crucial aspect of the SCP reasoning is that because ' $(S)$ tructure' determined ' $(\mathrm{C})$ onduct', which in turn determined '( $\mathrm{P})$ erformance', the mediating variable could be ignored, because the industry structure alone explained performance. Although in the updated version of SCP (with a reverse feedback effect added) Porter does not omit 'conduct', his interest focuses on fundamental structural parameters of an industry rather than on companies' intrinsic choices, which (if rational) should fall in the schema of a five-forces-game (Porter 1981).

Another issue is the examples of companies that Porter frequently uses, which suggest an ethnocentric American way of looking at the world or at least a triad-nations (USA, UE, Japan) dominated lens (Dunning 1993; Rugman and Cruz 1993): Microsoft and Intel showing how the superior bargaining power of a supplier influences the margins of PC assemblers; e-Bay explaining the demand side of economies of scale; and SAP having 
an effective customer switching costs strategy (Porter 2008). These are giant companies that have nearly monopolized their industries, or at least occupy vast segments of respective markets. Again, this is a strong reference to the tradition of IOE research, where so-called oligopoly theory (studying competitive interactions in those markets where a few firms' actions directly affect each other) has always been a prominent convention (Caves and Porter 1978; Chamberlin 1962; Phillips 1960). Under this premise, not only competitors but also suppliers and customers are perceived as rivals in rent appropriation, which simplifies the analysis but does not reflect the whole spectrum of business activities (Czakon 2005).

Porter's five-forces model is also usually criticized for being based on the assumption of perfect factor markets, which implies that firms' resources are homogenous (Wang 2014). The RBV proponents argue that the position of market leaders could not be explained if the value they offer was entirely the result of factors obtained from external markets (Barney 2014). Interestingly, if one analyses Porter's work without prejudice, multiple references can be found to firms' unique strengths as well. As he personally notes: "Simple observation clearly revealed that firms differed a great deal in performance even though they competed in the same industry. Therefore, while $\mathrm{IO}[\mathrm{E}]$ is useful for determining the likely average profitability of an industry, in its traditional form it clearly is not very useful for sorting out the different performances of different companies" (Porter 1981, p. 612).

In his dynamic theory of strategy framework (reproduced in Fig. 1.1), Porter does not exclude the idiosyncrasy of companies. On the contrary, he points out that what longitudinally impacts performance is the managerial choices that brought a company to a specific position (and determined initial conditions with reference to the starting point of analysis). Moreover, he indicates that there exists an interdependency loop between them and firm resources and 'activities'. The latter are "basic units of competitive advantage", which can also create other assets in the form of skills, organizational routines and knowledge (Porter 1991, p. 102). Also the notion of 'drivers' includes both internal and external "structural determinants of differences in the cost or buyer value of activities or groups of actions" (p. 100), such as economies of scale, government regulations, timing, localization and firm policy choices (p. 104). The core difference between his analysis and the RBV is the answer to the question: "to what extent the environment shapes initial conditions and choice, in contrast to idiosyncratic, creative decision-making process within the firm" (1991, p. 101). 


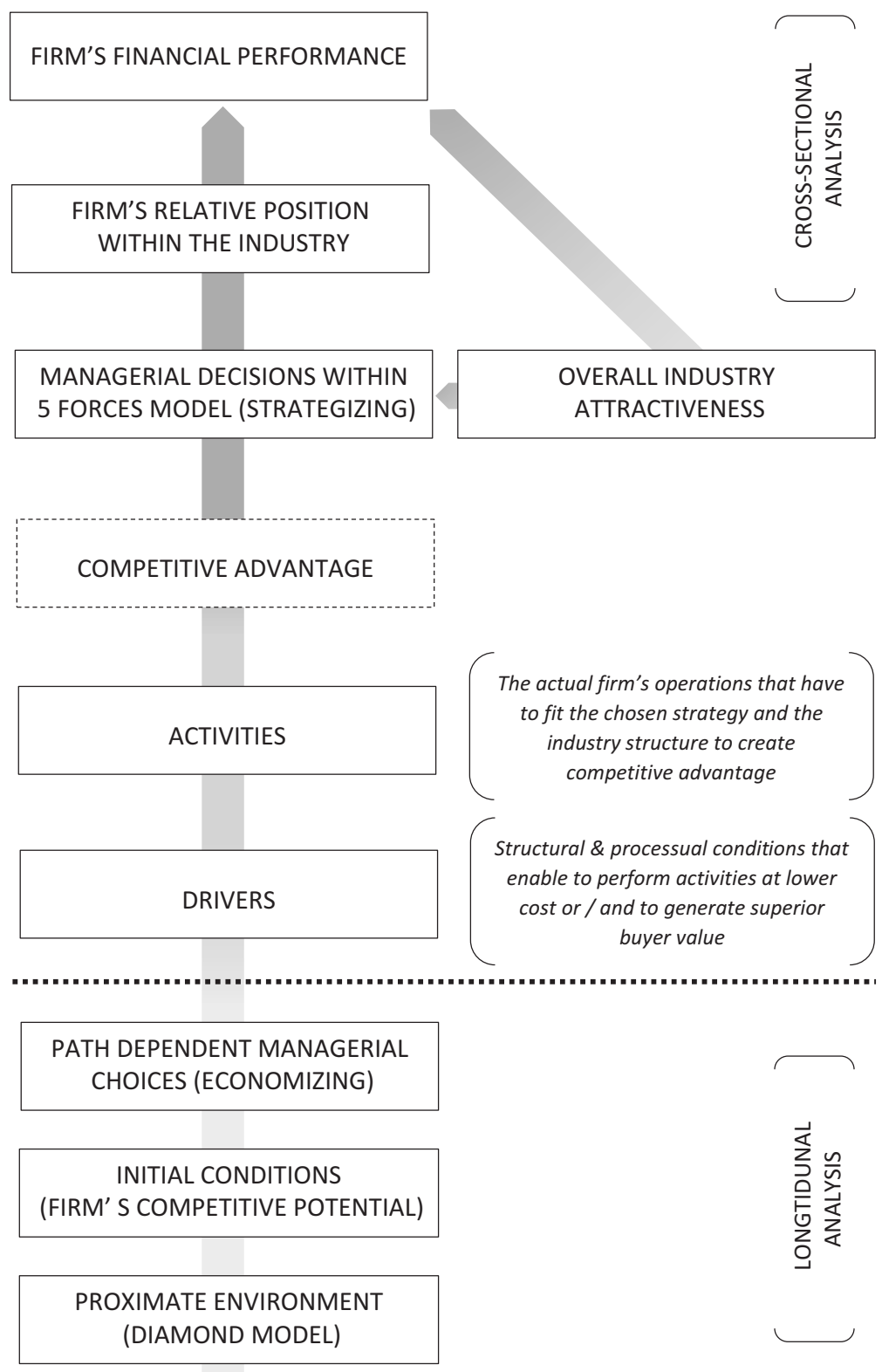

Fig. 1.1 Causal chain of interdependencies in M. Porter's dynamic theory of strategy. (Source: Adapted from Porter 1991, p. 100; van den Bosch 1997, p. 95) 
In search of "the origins of the origins", Porter builds his analysis upon the notion that the initial firm conditions are determined by past managerial choices, which, however, reflect the environmental pressure at that time (1991, p. 106). This is a typical economic perspective that sees the company from the outside, and its main theoretical goal is to provide a systematic understanding of differences and sustainability of profits in given industry environments (Wiktor 2019). Nonetheless, although in his model Porter situates the locus of competitive advantage in the market, he explains it as a consequence of a firm's own competitive drivers and activities. Only a firm's short-term financial performance is directly influenced by the overall industry attractiveness.

The RBV, in turn, clearly locates its interest inside a company. Traditionally, the origins of this school are placed in the work of E. Penrose (2009 (1959); 1960), at least at the descriptive level (the crucial role of resources and specialization determining the expansion of a firm; Rugman and Verbeke 2004). However, the idea of studying how a single business entity works is much older. For example, in the nineteenth century, J. Say developed A. Smith's definition of productive labour, pointing out the role of an entrepreneur, who can effectively make use of their own organizational and management skills and borrowed capital to create added value (Kunasz 2006).

The basic assumptions of the RBV (related to the earlier excerpted IOE assumptions) are as follows (Andrews 1971; Barney 1997; Peteraf 1993; Teece et al. 1997; Wernerfelt 1984):

- the differences in firm performance are a function of their internal heterogeneity;

- competitive advantage is built on VRIO resources (valuable, rare, difficult to imitate, organized);

- a strategy is the act of aligning and developing what the company can do particularly well with environmental opportunities;

- the success of a company results from the deployment of resources so that they produce value that can be monetized in the market, while preserving their unique character;

- the three generic ways of achieving a competitive advantage are based on non-generic strategic assets.

The fundamental notion of the RBV is its definition of a company as a "bundle of resources and capabilities" (Amit and Schoemaker 1993, 
p. 37). Some of them are extraordinarily valuable, as well as rare; difficult to imitate, substitute and trade; durable; well organized (appropriable) and complementary (co-specialized; Barney 1986a; Ciszewska-Mlinarič and Wąsowska 2015; Teece 1986). Because of their unique character they can be labelled 'strategic assets' - assets that have the potential to generate a sustainable competitive advantage for the company (Amit and Schoemaker 1993).

Analogous to the industry entry barriers in the IOE, the RBV distinguishes 'isolating mechanisms', which can be understood as knowledgebased, physical or legal barriers that prevent competitors imitating and undoing the competitive advantage of a successful company (Lepak et al. 2007). Some of them are even shared with the IOE: patents, trademarks, consumer switching and search costs, producer sunk costs and so on (Rumelt 1997, p. 141). But more specifically, the RBV-style isolating mechanisms refer to path-dependent asset specificity based on causal ambiguity, social complexity, time compression diseconomies, hard-toreverse commitments and partner asset interconnectedness (Barney 1991; Dierickx and Cool 1989; Dyer and Singh 1998; Ghemawat 1991; Lippman and Rumelt 1982; Teece 2007). In turn, such intangible assets emerge as, for example, reputation, trust and commitment, effective corporate culture, unique knowledge and partner-specific absorptive capacity. They are not traded in the factor markets, nor can they be quickly replicated. In fact, these resources are not only perfectly immobile and of highly limited supply, but their strong tacit and history-dependent dimension, which is a function of successive decisions affected by managerial bounded rationality (inward-oriented choices that underestimate some facts while overestimating others; Bratnicki and Dyduch 2020; Mahoney and Pandian 1992), makes them hardly definable even by the companies they belong to, let alone would-be imitating competitors (Teece et al. 1994). Many of them may even be too idiosyncratic to retain the same value outside of the host company or business network (Rumelt 1987). This implies that their value in a native state (ex ante cost of acquisition) was well below their value once appropriated and developed by the firm (ex post value); or alternatively, the company was far better at accumulating and developing these classes of resources than its competitors, even if they had recognized them early and anticipated their potential ex post value (Peteraf 1993). These two conditions decide on the prospects of a company to generate a sustainable competitive advantage and the consequent above-average rents. 
The heterogeneity of companies is especially present in their activities. As some resources can be obtained in the factor markets, companies may be, to some extent, comparable in this respect (Amit and Schoemaker 1993). Moreover, a company may have a unique understanding, for example, of a technically complex process (technical competence), but this does not mean it has the capability to effectively market it at a profit (Dyduch and Bratnicki 2015). Just as in the Parable of Talents, even precious resources are unproductive if not used. Meanwhile, the notion of company-specific 'resource conversion activities' has always been present in the resource-based way of thinking (Rumelt 1984, p. 561). But it was not until D. Teece et al.'s seminal article (1997) followed by many other scholars (Eisenhardt and Martin 2000; Winter 2003) that 'dynamic capabilities' were advanced as a fundamental extension of RBV. These authors locate the most important activities of a company in learning processes, as well as in the continuous integration and reconfiguration of internal and external resources (Teece et al. 1997). The missing link between these resources and company performance is processes of complex interactions (Wu 2007), which prolifically deal with the competitive business environment (Shams 2016). Dynamic capabilities are therefore managerial and organizational processes that refer to the way coordination, learning and transformation are done in the company. They are, in turn, manifested in organizational routines, which are group and individual patterns of behaviour that represent successful solutions to particular problems (Mitręga et al. 2012; Teece et al. 1997).

Dynamic capabilities link the internal environment of the company with the outer world, which by definition implies that industry analysis remains a vital part of research in management. This reflects the dual nature of competitive advantage and suggests that the dichotomist approaches of the IOE and the classic RBV on the roots of competitive advantage are matters of analytical focus and of methodological convenience. There were (and still are) attempts being made to combine both views into one coherent approach. For example, G. Hooley et al. (2001) developed a concept of strategic positioning, which they define as the combination of competitive advantage (how the firm will compete) and choice of target market (where the firm will compete). Figure 1.2 depicts the interactions between the key firm and industry constructs in R. Amit and P. Shoemaker's model of strategic assets and organizational rent (1993). These scholars incorporate the IOE tradition in the form of 'strategic industry factors', which include Porter's five-forces model 


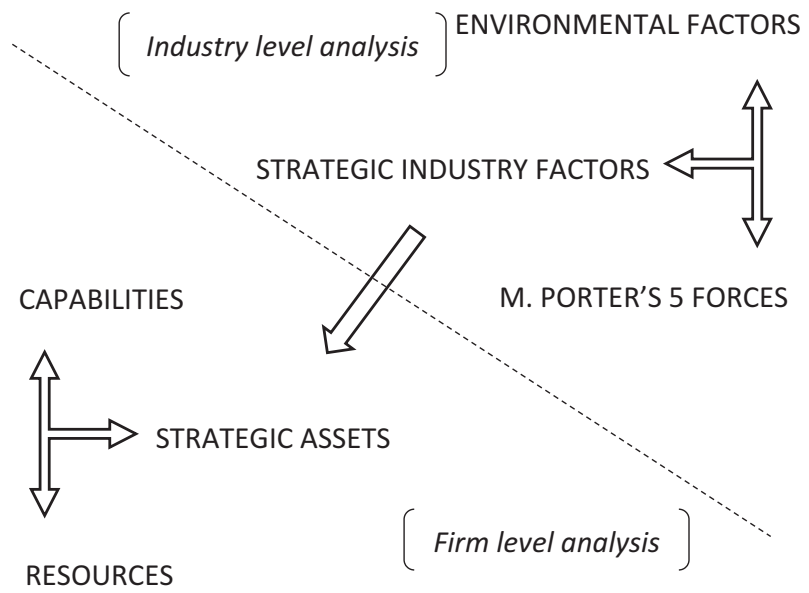

Fig. 1.2 Strategic assets and strategic industry factors. (Adapted from Amit and Schoemaker (1993, p. 37))

supplemented by 'environmental factors' (changes in technology, regulation, etc.). They insist that, to be useful, the company's strategic assets have to overlap with the strategic industry factors (1993, p. 37). Perhaps the most comprehensive theory, which simultaneously builds on the IOE and RBV research traditions, is the Resource-Advantage Theory of Competition (R-A theory; Hunt and Morgan 1996). A more detailed reference to R-A theory will be made in the next chapter during the discussion on the scope of the envisioned RM mid-range theory.

What the IOE and RBV theories undoubtedly have in common is that they mainly depict a market situation of competing entities. However, companies can appropriate substantial rents not only generated from their own resources but also resulting from the resources of their business partners, provided within a long-lasting joint venture or even during a temporal project (Gołębiowski and Lewandowska 2015). A network rent (or in a narrower sense a relational rent) will depend, inter alia, on the value of these resources, the absorptive capability of cooperating partners and the relationship governance model (Dyer and Singh 1998). The same mechanism can be reflected in a $\mathrm{B} 2 \mathrm{C}$ setting or in any other situation where synergies exist that create conditions for an exchange based on a non-zero sum game (Deszczyński 2016). However, provided both partners stay as independent subjects of a relationship, volatile 'coopetition' behaviours 
are possible (more/less cooperation/competition; Bengtsson and Kock 2000). On one hand, this reflects the RBV style of economizing based on strategic resources and capabilities. On the other, it resembles the IOE style of strategizing in the way companies adjust their positions in an inherently unbalanced partnership or a network setting (Birkinshaw et al. 2001; Jankowska 2009). This creates a situation of a unique relationship dynamism and the necessity to manage multiple relationships.

\section{REFERENCES}

Amit, Raphael, and Paul J.H. Schoemaker. 1993. Strategic Assets and Organizational Rent. Strategic Management Journal 14 (1): 33-46. https:// doi.org/10.1002/smj.4250140105.

Andrews, Kenneth R. 1971. The Concept of Corporate Strategy. In Historical Evolution of Strategic Management, 18-46. Homewood: Dow-Jones Irwin. https://doi.org/10.4324/9781315253336-11.

Bain, Joe Staten. 1968. Industrial Organization. 2nd ed. New York: John Wiley \& Sons Inc.

Banaszyk, Piotr. 2014. Model Biznesu Jako Podstawa Zarządzania Strategicznego Przedsiębiorstwem. Zeszyty Nankowe Akademii Ekonomicznej w Poznaniu 43: 7-27.

Barney, Jay B. 1986a. Organizational Culture: Can It Be a Source of Sustained Competitive Advantage? The Academy of Management Review 11 (3): 656-665. https://doi.org/10.2307/258317.

- 1986b. Strategic Factor Markets: Expectations, Luck, and Business Strategy. Management Science 32 (10): 1231-1241.https://doi.org/10.1287/ mnsc.32.10.1231.

- 1991. Firm Resources and Sustained Competitive Advantage. Journal of Management 17 (1): 99-120. https://doi.org/10.1177/014920639101 700108 .

- 1997. Gaining and Sustaining Competitive Advantage. Reading: AddisonWesley Publishing Company.

- 2014. How Marketing Scholars Might Help Address Issues in ResourceBased Theory. Journal of the Academy of Marketing Science 42 (1): 24-26. https://doi.org/10.1007/s11747-013-0351-8.

Bass, Frank M., A. Krishnamoorthy, Ashutosh Prasad, and Suresh P. Sethi. 2004. Advertising Competition with Market Expansion for Finite Horizon Firms. Journal of Industrial and Management Optimization. https://utd-ir.tdl.org/ handle/10735.1/3643. 
Bengtsson, Maria, and Sören Kock. 2000. "Coopetition" in Business Networks to Cooperate and Compete Simultaneously. Industrial Marketing Management 29 (5): 411-426. https://doi.org/10.1016/S0019-8501(99)00067-X.

Bharadwaj, Sundar G., P. Rajan Varadarajan, and John Fahy. 1993. Sustainable Competitive Advantage in Service Industries: A Conceptual Model and Research Propositions. Journal of Marketing 57 (4): 83-99. https://doi. org/10.2307/1252221.

Bingham, Christopher B., and Kathleen M. Eisenhardt. 2008. Position, Leverage and Opportunity: A Typology of Strategic Logics Linking Resources with Competitive Advantage. Managerial and Decision Economics 29 (2-3): 241-256. https://doi.org/10.1002/mde.1386.

Birkinshaw, Julian, Omar Toulan, and David Arnold. 2001. Global Account Management in Multinational Corporations: Theory and Evidence. Journal of International Business Studies 32 (2): 231-248. https://doi.org/10.1057/ palgrave.jibs.8490950.

Bratnicki, Mariusz, and Wojciech Dyduch. 2020. Understanding Cognitive Biases in Strategic Decisions for Value Creation and Capture. In Contemporary Challenges in Cooperation and Coopetition in the Age of Industry 4.0, Springer Proceedings in Business and Economics, ed. Agnieszka Zakrzewska-Bielawska and Iwona Staniec, 359-373. Cham: Springer International Publishing. https://doi.org/10.1007/978-3-030-30549-9_19.

Buckley, Peter J., Christopher L. Pass, and Kate Prescott. 1988. Measures of International Competitiveness: A Critical Survey. Journal of Marketing Management 4 (2): 175-200. https://doi.org/10.1080/0267257X. 1988.9964068 .

Caves, R.E., and Michael E. Porter. 1978. Market Structure, Oligopoly, and Stability of Market Shares. The Journal of Industrial Economics 26 (4): 289-313. https://doi.org/10.2307/2098076.

Chamberlin, E. H. (1962). The theory of monopolistic competition-a reorientation of the theory of value. Cambridge: Harvard University.

Ciszewska-Mlinarič, Mariola, and Aleksandra Wąsowska. 2015. Resource-Based View (RBV). In Wiley Encyclopedia of Management, 1-7. American Cancer Society. https://doi.org/10.1002/9781118785317.weom060174.

Conner, Kathleen R. 1991. A Historical Comparison of Resource-Based Theory and Five Schools of Thought Within Industrial Organization Economics: Do We Have a New Theory of the Firm? Journal of Management 17 (1): 121-154. https://doi.org/10.1177/014920639101700109.

Coyne, Kevin P. 1986. Sustainable Competitive Advantage-What It Is, What It Isn't. Business Horizons 29 (1): 54.

Czakon, Wojciech. 2005. Ku Systemowej Teorii Przewagi Konkurencyjnej Przedsiębiorstwa. Przegląd Organizacji 5: 5-8. 
2014. Szkoły a Mody w Zarządzaniu Strategicznym. Prace Naukowe WWSZIP 27 (2): 47-55.

Deszczyński, Bartosz. 2016. The Impact of Opportunity Management on the Relationship Business Model (A Study in the Polish Housing Industry). Journal of Eastern European and Central Asian Research (JEECAR) 3 (2): 1-10. https://doi.org/10.15549/jeecar.v3i2.137.

Dierickx, Ingemar, and Karel Cool. 1989. Asset Stock Accumulation and Sustainability of Competitive Advantage. Management Science 35 (12): 1504-1511. https://doi.org/10.1287/mnsc.35.12.1504.

Dunning, John H. 1993. Internationalizing Porter's Diamond. MIR: Management International Review 33: 7-15.

Dyduch, Wojciech, and Mariusz Bratnicki. 2015. Tworzenie i przechwytywanie wartości w organizacjach współdziałających w sieci. Prace Naukowe Wałbrzyskiej Wyższej Szkoty Zarzadzania i Przedsiębiorczości 32 (2): 77-93.

Dyer, Jeffrey H., and Harbir Singh. 1998. The Relational View: Cooperative Strategy and Sources of Interorganizational Competitive Advantage. The Academy of Management Review 23 (4): 660-679. https://doi. org/10.2307/259056.

Eisenhardt, Kathleen M., and Jeffrey A. Martin. 2000. Dynamic Capabilities: What Are They? Strategic Management Journal 21 (10-11): 1105-1121. https://doi.org/10.1002/1097-0266(200010/11)21:10/11<1105:: AID-SMJ133>3.0.CO;2-E.

Ghemawat, Pankaj. 1991. Commitment: The Dynamic of Strategy. New York/ Toronto: Free Press.

Gołębiowski, Tomasz, and Małgorzata Stefania Lewandowska. 2015. Influence of Internal and External Relationships of Foreign Subsidiaries on Innovation Performance. Evidence from Germany, Czech Republic and Romania. Journal of East European Management Studies 20 (3): 304-327.

Hooley, Graham, Gordon Greenley, John Fahy, and John Cadogan. 2001. MarketFocused Resources, Competitive Positioning and Firm Performance. Journal of Marketing Management 17 (5-6): 503-520. https://doi. org/10.1362/026725701323366908.

Hunt, Shelby D., and Robert M. Morgan. 1996. The Resource-Advantage Theory of Competition: Dynamics, Path Dependencies, and Evolutionary Dimensions. Journal of Marketing: 107-114.

Jankowska, Barbara. 2009. Competition or Cooperation? (Konkurencja czy kooperacja?). Ekonomista (The Economist) 1: 67-89.

Klein, Benjamin, and Keith B. Leffler. 1981. The Role of Market Forces in Assuring Contractual Performance. Journal of Political Economy 89 (4): 615-641. https://doi.org/10.1086/260996. 
Krupski, Rafał. 2009a. Strategia Jako System UC. In Koncepcje Strategii Organizacji, ed. Rafał Krupski, Jerzy Niemczyk, and Ewa Stańczyk-Hugiet, 23-44. Warszawa: Polskie Wydawnictwo Ekonomiczne.

- 2009b. Teleologiczny Kontekst Elastyczności Strategii. Ed. Rafał Krupski, Jerzy Niemczyk, and Stańczyk-Hugiet, 155-68. Warszawa: Polskie Wydawnictwo Ekonomiczne.

Kunasz, Marek. 2006. Zasoby przedsiębiorstwa w teorii ekonomii. Gospodarka Narodowa 211 (10): 33-48. https://doi.org/10.33119/GN/101446.

Lepak, David P., Ken G. Smith, and M. Susan Taylor. 2007. Value Creation and Value Capture: A Multilevel Perspective. Academy of Management Review 32 (1): 180-194. https://doi.org/10.5465/amr.2007.23464011.

Lichtarski, Jan. 2015. Praktyczny Wymiar Nauk o Zarządzaniu. Warszawa: Polskie Wydawnictwo Ekonomiczne.

Lippman, Steven A., and Richard P. Rumelt. 1982. Uncertain Imitability: An Analysis of Interfirm Differences in Efficiency Under Competition. The Bell Journal of Economics 13 (2): 418-438. https://doi.org/10.2307/3003464.

Mahoney, Joseph T., and J. Rajendran Pandian. 1992. The Resource-Based View within the Conversation of Strategic Management. Strategic Management Journal 13 (5): 363-380. https://doi.org/10.1002/smj.4250130505.

Mawdsley, John K., and Deepak Somaya. 2018. Demand-Side Strategy, Relational Advantage, and Partner-Driven Corporate Scope: The Case for Client-led Diversification. Strategic Management Journal 39 (7): 1834-1859.

Mintzberg, Henry, and Joseph Lampel. 1999. Reflecting on the Strategy Process. Sloan Management Review 40 (3): 21-30.

Mitręga, Maciej, Sebastian Forkmann, Carla Ramos, and Stephan C. Henneberg. 2012. Networking Capability in Business Relationships Concept and Scale Development. Industrial Marketing Management, IMP 2011 The Impact of Globalization on Networks, 4l (5): 739-751. https://doi.org/10.1016/j. indmarman.2012.06.002.

Montgomery, Cynthia A., and Birger Wernerfelt. 1988. Diversification, Ricardian Rents, and Tobin's q. The RAND Journal of Economics 19 (4): 623-632. https://doi.org/10.2307/2555461.

Niemczyk, Jerzy. 2009. Filozofie i Szkoły Strategii. In Koncepcje Strategii Organizacji, ed. Rafał Krupski, Jerzy Niemczyk, and Stańczyk-Hugiet, 11-23. Warszawa: Polskie Wydawnictwo Ekonomiczne.

Obłój, Krzysztof. 1998. Strategia Sukcesu Firmy. Warszawa: Polskie Wydawnictwo Ekonomiczne.

- 2002. Tworzywo Skutecznych Strategii. Warszawa: Polskie Wydawnictwo Ekonomiczne.

—. 2007. Strategia Organizacji. Warszawa: Polskie Wydawnictwo Ekonomiczne. 
2013. The Passion and Discipline of Strategy. London: Palgrave Macmillan UK. https://doi.org/10.1057/9781137334947_1.

- 2019. Pasja i Dyscyplina Strategii. Jak z Marzeń i Decyzji Zbudować Sukces Firmy. Warszawa: Poltext.

Penrose, Edith T. 1960. The Growth of the Firm - A Case Study: The Hercules Powder Company. Business History Review (Pre-1986) 34 (000001): 1.

. 2009. The Theory of the Growth of the Firm. Oxford: Oxford University Press.

Peteraf, Margaret A. 1993. The Cornerstones of Competitive Advantage: A Resource-Based View. Strategic Management Journal 14 (3): 179-191. https://doi.org/10.1002/smj.4250140303.

Peteraf, Margaret A., and Jay B. Barney. 2003. Unraveling the Resource-Based Tangle. Managerial and Decision Economics 24 (4): 309-323. https://doi. org/10.1002/mde.1126.

Phillips, Almarin. 1960. A Theory of Interfirm Organization. The Quarterly Journal of Economics 74 (4): 602-613. https://doi.org/10.2307/1884355.

Porter, Michael E. 1979. How Competitive Forces Shape Strategy. Harvard Business Review, March 1. https://hbr.org/1979/03/how-competitiveforces-shape-strategy

- 1980. Industry Structure and Competitive Strategy: Keys to Profitability. Financial Analysts Journal 36 (4): 30-41. https://doi.org/10.2469/faj. v36.n4.30.

- 1981. The Contributions of Industrial Organization to Strategic Management. Academy of Management Review 6 (4): 609-620. https://doi. org/10.5465/amr.1981.4285706.

- 1991. Towards a Dynamic Theory of Strategy. Strategic Management Journal 12 (S2): 95-117. https://doi.org/10.1002/smj.4250121008.

- 2008. The Five Competitive Forces That Shape Strategy. Harvard Business Review, January 1. https://hbr.org/2008/01/the-five-competitive-forcesthat-shape-strategy.

Romanowska, Maria. 2018. Idea spójności w zarządzaniu strategicznym. Przegląd Organizacji 6: 3-9. https://doi.org/10.33141/po.2018.6.1.

Rugman, Alan M., and Alain Verbeke. 2004. A Final Word on Edith Penrose. Journal of Management Studies 41 (1): 205-217. https://doi. org/10.1111/j.1467-6486.2004.00429.x.

Rumelt, Richard P. 1984. Towards a Strategic Theory of the Firm. Competitive Strategic Management 26 (3): 556-570.

- 1987. Theory, Strategy, and Entrepreneurship. In The Competitive Challenge., ed. David Teece, 137-158. Cambridge, MA: Ballinger.

- 1997. Towards a Strategic Theory of the Firm. In Resources, Firms, and Strategies: A Reader in the Resource-Based Perspective, ed. Nicolai J. Foss, 137-145. Oxford: Oxford University Press. 
Rumelt, Richard P., D. Schendel, and David J. Teece. 1995. Fundamental Issues in Strategy: A Research Agenda. Cambridge, MA: Harvard Business School Press. https://books.google.pl/books?id=rttTzECN9_YC.

Schumpeter, J.A. 2010 (1950). Capitalism, Socialism and Democracy: 1st Edition (Paperback). Abingdon: Routledge.

Shams, S.M. Riad. 2016. Capacity Building for Sustained Competitive Advantage: A Conceptual Framework. Marketing Intelligence \& Planning 34 (5): 671-691. https://doi.org/10.1108/MIP-08-2015-0161.

Shapiro, Carl. 1989. The Theory of Business Strategy. The RAND Journal of Economics 20 (1): 125-137. https://doi.org/10.2307/2555656.

Sigalas, Christos. 2013. Developing a Measure of Competitive Advantage. Journal of Strategy and Management 6 (4): 320-342. https://doi.org/10.1108/ JSMA-03-2013-0015.

Sobczyk, Janusz R. 2010. Kryzys podstaw metodologicznych nauk o zarządzaniu kryzysem powinowactwa z naukami społecznymi. Acta Universitatis LodzensisFolia Oeconomica 234: 335-345.

Teece, David J. 1984. Economic Analysis and Strategic Management. California Management Review (Pre-1986); Berkeley 26 (3, Spring): 87.

- 1986. Profiting from Technological Innovation. Research Policy 15: 285-305.

2007. Explicating Dynamic Capabilities: The Nature and Microfoundations of (Sustainable) Enterprise Performance. Strategic Management Journal 28 (13): 1319-1350. https://doi.org/10.1002/smj.640.

Teece, David J., Richard Rumelt, Giovanni Dosi, and Sidney Winter. 1994. Understanding Corporate Coherence: Theory and Evidence. Journal of Economic Behavior \& Organization 23 (1): 1-30. https://doi. org/10.1016/0167-2681(94)90094-9.

Teece, David J., Gary Pisano, and Amy Shuen. 1997. Dynamic Capabilities and Strategic Management. Strategic Management Journal 18 (7): 509-533. https://doi.org/10.1002/(SICI)1097-0266(199708)18:7<509:: AID-SMJ882>3.0.CO;2-Z.

Trocki, Michał. 2005. Toěsamość nauk o zarządzaniu. Przegląd Organizacji 1:7-10. van den Bosch, Frans A.J. 1997. Porter's Contribution to More General and Dynamic Strategy Frameworks. In Perspectives on Strategy: Contributions of Michael E. Porter, ed. F.A.J. van den Bosch and A.P. De Man, 91-100. Boston: Springer US. https://doi.org/10.1007/978-1-4615-6179-8_10.

Wang, Hui-Ling. 2014. Theories for Competitive Advantage. In Being Practical with Theory: A Window into Business Research, ed. H. Hasan, 33-43. Wollongong: THEORI. https://ro.uow.edu.au/buspapers/408.

Wernerfelt, Birger. 1984. A Resource-Based View of the Firm. Strategic Management Journal 5 (2): 171-180. https://doi.org/10.1002/ smj.4250050207. 
Wiktor, Jan. 2019. Koncepcja Konkurencji M.E. Portera a System Ochrony Rynku Wewnętrznego Unii Europejskiej. Przegląd Organizacji 6: 9-16. https://doi. org/10.33141/po.2019.6.1.

Williamson, Oliver E. 1983. Credible Commitments: Using Hostages to Support Exchange. The American Economic Review 73 (4): 519-540.

- 1991. Strategizing, Economizing, and Economic Organization. Strategic Management Journal 12 (S2): 75-94. https://doi.org/10.1002/ smj.4250121007.

Winter, Sidney G. 2003. Understanding Dynamic Capabilities. Strategic Management Journal 24 (10): 991-995. https://doi.org/10.1002/smj.318.

Wu, Lei-Yu. 2007. Entrepreneurial Resources, Dynamic Capabilities and Start-Up Performance of Taiwan's High-Tech Firms. Journal of Business Research 60 (5): 549-555. https://doi.org/10.1016/j.jbusres.2007.01.007.

Zimniewicz, Kazimierz. 2014. Teoria i Praktyka Zarzadzania: Analiza Krytyczna. Warszawa: Polskie Wydawnictwo Ekonomiczne.

Open Access This chapter is licensed under the terms of the Creative Commons Attribution 4.0 International License (http://creativecommons.org/licenses/ by $/ 4.0 /)$, which permits use, sharing, adaptation, distribution and reproduction in any medium or format, as long as you give appropriate credit to the original author(s) and the source, provide a link to the Creative Commons licence and indicate if changes were made.

The images or other third party material in this chapter are included in the chapter's Creative Commons licence, unless indicated otherwise in a credit line to the material. If material is not included in the chapter's Creative Commons licence and your intended use is not permitted by statutory regulation or exceeds the permitted use, you will need to obtain permission directly from the copyright holder.

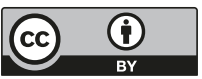

